\title{
Analysis of Changes Induced In Human Periodontal Ligament, Dental Pulp, Bone Marrow and Adipose Stem Cells by Low Level Laser Therapy: A Review and New Perspectives
}

\author{
Vincenzo Grassia ${ }^{1}$, Maddalena Vitale ${ }^{1}$, Fabrizia d'Apuzzo ${ }^{1}$, Alessio Paiusco ${ }^{2}$, Gianluigi Caccianiga ${ }^{2}$ and \\ Letizia Perillo*1 \\ ${ }^{1}$ Multidisciplinary Department of Medical-Surgical and Dental Specialties, University of Campania Luigi Vanvitelli, Italy
}

${ }^{2}$ Department of Medicine and Surgery, University of Milano Bicocca, Italy

Received: April 24, 2018; Published: May 07, 2018

*Corresponding author: Letizia Perillo, Multidisciplinary Department of Medical-Surgical and Dental Specialties, University of Campania Luigi Vanvitelli, Via L De Crecchio 6, 80138 Naples, Italy

\begin{abstract}
The biomodulation and the biostimulation of Low Level Laser Therapy (LLLT) promote wound healing, dentine repairing processes and stimulate the biological activity of human Periodontal Ligament Stem Cells (HPDLSCs), human Dental Pulp Stem Cells (HDPSCs), human Bone Marrow Stem Cells (HBMSCs) and human Adipose Stem Cells (HADSCs). The aim of the study was to review the literature on the LLLT effects on HPDLSCs, HDPSCs, HBMSCs and HADSCs. The electronic search was performed collecting articles in the PubMed, Medline, Scopus, Lilacs and Google Scholar databases from January 1990 to January 2018. LLLT was able to significantly increase HPDLSCs, HDPSCs, HBMSCs and HADSCs proliferation rate, stimulating osteogenic differentiation and opening new possibilities in the tissue regeneration. However, the research background on this topic showed high heterogeneity and the in vitro studies cannot always mimic the in vivo conditions. Thus, further clinical studies should be performed to determine the appropriate dose of irradiation in different patients.

Abbreviations: LLLT: Low Level Laser Therapy; HPDLSCs: Human Periodontal Ligament Stem Cells; HDPSCs: Human Dental Pulp Stem Cells; HBMSCs: Human Bone Marrow Stem Cells; HADSCs: Human Adipose Stem Cells; OXPHOS: Oxidative Phosphorylation; ETC: Electron Transport Chain; ATP: Adenosine Triphosphate; PDL: Periodontal Ligament
\end{abstract}

\section{Introduction}

In 1967, Endre Mester, a Hungarian physician, after applying low-power laser light to shaved mice noticed a faster hair growth compared to the control group [1,2]. This was a new non-surgical way of use the laser: instead of incise and coagulate tissues many researchers started to investigate the enhancing and stimulating effects of light. Currently the Low-Level Laser Therapy (LLLT), also called "cold laser therapy" is known for biostimulatory and biomodulatory effects in vivo and in vitro. The LLLT shows not a thermal but photochemical effect by triggering biochemical changes within cells after the application of a light ranging between $10 \mathrm{~mW}-500 \mathrm{~mW}$. The result of Low-Level Laser irradiance on human tissues is a reduction of inflammation, pain relief and accelerated tissue regeneration. In dentistry, the use of LLLT is increasing in the last years because it promotes wound-healing, dentine repairing processes and stimulates the biological activity of mesenchymal stem cells (MSCs) and human periodontal ligament stem cells (HPDLSCs) [3-26]. MSCs can differentiate into different specialized cell types and they can be identified and collected in humans from dental pulp steam cells (HDPSCs) [11,27-38], adipose tissue [39$45]$ and cancellous portions of bones [46,47]. The LLLT effects on cell proliferation have been investigated by several authors but the main part of the papers do not focus properly on HPDLSCs and HDPSCs, which could open new possibilities in regenerative medicine and dentistry. Therefore, the objective of the present study was to review the literature about the LLLT effects on the HPDLSCs and HDPSCs, but also on HBMSCs and HADSCs.

\section{Methods}

The electronic databases searched for eligible relevant scientific papers from January 1990 to January 2018 were Medline via 
PubMed, Scopus, Cochrane Central Register of Controlled Trials via Cochrane Library, Lilac and Google Scholar databases. There was no language restriction set. Inclusion criteria were studies evaluating effects of LLLT on HPDLSCs, HDPSCs, HBMSCs and HADSCs. Papers that did not provide specifically data about HPDLSCs HDPSCs, HBMSCs and HADSCs were excluded. Reference lists of the selected articles were also hand-searched for other relevant papers that may have been missed by the search engines. The titles and abstracts of all studies resulting from the search were independently assessed by two reviewers. Full copies of all apparently relevant studies or those for which there were insufficient data in the title and abstract to make decision, were obtained. Any disagreement between the two reviewers on the eligibility of included studies was resolved through oral discussion and consensus. Studies that did not match the inclusion criteria in this second selection phase were excluded.

\section{Mechanism of LLLT Action}

It has been shown that LLLT can augment the oxidative phosphorylation (OXPHOS) modifying the redox basal-status of the whole cell and in particular of mitochondria [6,48]. During OXPHOS, thanks to electron transport chain (ETC), electrons are shifted from a reducing agent (even called electron donors) to oxidizing agent (even called electron acceptors), which in biological reduction-oxidation (redox) reactions is the oxygen (02) [49]. These redox reactions free energy that is mainly spent to synthetize chemical energy: the adenosine triphosphate (ATP) [50-52]. The mechanism of LLLT is based on the absorption of a specific visible red and near-infrared wavelengths by biological photoreceptors located inside human cells, augmenting the production of a trans-membrane electric and mechanical proton- $\mathrm{H}+$ gradient in mitochondria necessary for OXPHOS [53-57], and enhancing the activity of mitochondrial complexes IV in an exposure-response relationship [58,59]. In addition, there is evidence that LLLT affects the mastocytes cells localized into endothelium in mucous membranes and dental pulp [4,60,61].

a) Laser stimulation can induce mast cells degranulation: although they show a key role in endothelial-leukocyte adhesion molecules and anaphylaxis, the labrocytes have a great defensive role too, being engaged in wound healing, angioneogenesis, protecting from infectious agents and getting involved in bloodbrain barrier action [62-64]. In conclusion, LLLT influences the biological function of a variety of cell types by stimulating mitochondrial OXPHOS and modulating inflammatory responses, exerting a range of several beneficial effects upon cell proliferation and healing.

\section{Effects on HPDLSCs}

The periodontium (from $\pi \varepsilon \rho$ í: peri- "around" and -odont "tooth") is a specialized tissue surrounding the teeth composed by cementum, periodontal ligament (PDL), gingiva and alveolar cortex [65]. The PDL is a membrane-like connective tissue interposed between the tooth root and the alveolar bone of which the main component is represented by collagen fibers. It grants mechanical resistance during masticatory forces and control alveolar bone turnover maintaining tissue homeostasis and dissipating forces during physiological or orthodontic tooth movement [21,66,67]. hPDLSCs has the faculty for self-renewal and the capacity to differentiate into different cell pools like cement oblasts and osteoblasts, which contribute to the repair of affected cementum and alveolar bone leading to a partial or complete periodontal regeneration [68-71].

For this reason, it is meaningful the possibility to stimulate HPDLSCs proliferation and differentiation to improve periodontal tissue regeneration [72]. Moreover LLLT helps pain reliefs through an increased synthesis of prostaglandin E2, interleukin-1b and osteocalcin during tooth movement $[73,74]$, and the decreasing levels of plasminogen activator under mechanical stress [70,7580]. Kreisle [81,82] reported that the irradiated test group revealed a highly significant proliferation rate $24 \mathrm{~h}$ after diode laser exposure at a power output of $10 \mathrm{~mW}$ in continuous wave modality at energy fluencies of $1.96-7.84 \mathrm{~J} / \mathrm{cm}^{2}$ compared to control group. Similarly Hakki [4] that observed a significant increase of collagen I mRNA expression only in the LLLT bio-stimulated group. Wu [21] observed an augmented proliferation and osteogenic differentiation of hPDLSCs via cAMP regulation with a low-power GaAlAs 660-nm at $2 \mathrm{~J} / \mathrm{cm}^{2}$, highlighting possible osteogenic inducibility of LLLT during periodontal tissue regeneration procedures [76]. Soares [83] showed that a power of $30 \mathrm{~mW}$ at $1.0 \mathrm{~J} / \mathrm{cm} 2$ has stimulating effects while under that parameters he noticed just a small changing on the proliferation rate of hPDLSC. In addition, it was observed an accumulative effect between repeated irradiation. According to the growth curve, the effect was greater when the test-group cells were irradiated with the dose of $1.0 \mathrm{~J} / \mathrm{cm}^{2}$ compared to $0.5 \mathrm{~J} / \mathrm{cm}^{2}$, in particular at $48 \mathrm{~h}$ and $72 \mathrm{~h}$ after the second laser stimulation. Huang [73] noticed higher viability of hPDLSCs at both 5 and $10 \mathrm{~J} / \mathrm{cm}^{2}$ than the control group at day 7 .

Table 1: Main papers of LLLT on HPDLSCs.

\begin{tabular}{|c|c|c|c|}
\hline $\begin{array}{l}\text { Authors } \\
\text { (Year) }\end{array}$ & $\begin{array}{c}\text { Laser } \\
\text { (Wavelength) }\end{array}$ & $\begin{array}{c}\text { Cell/Tissue } \\
\text { Examined }\end{array}$ & Conclusion \\
\hline $\begin{array}{l}\text { Kreisler et } \\
\text { al. (2002) }\end{array}$ & diode $(809 \mathrm{~nm})$ & $\begin{array}{c}\text { human } \\
\text { gingival } \\
\text { fibroblasts }\end{array}$ & $\begin{array}{l}\text { Highly significant } \\
\text { proliferation activity } \\
\text { after irradiation }\end{array}$ \\
\hline $\begin{array}{c}\text { Hakki et al. } \\
\text { (2010) }\end{array}$ & diode $(940 \mathrm{~nm})$ & $\begin{array}{l}\text { human } \\
\text { gingival } \\
\text { fibroblasts }\end{array}$ & $\begin{array}{l}\text { Significant increase } \\
\text { of collagen I mRNA } \\
\text { expression in LLLT } \\
\text { biostimulated group }\end{array}$ \\
\hline $\begin{array}{l}\text { Wu et al. } \\
\text { (2013) }\end{array}$ & $\begin{array}{l}\text { GaAlAs } \\
(660 \mathrm{~nm})\end{array}$ & $\begin{array}{c}\text { human } \\
\text { periodontal } \\
\text { ligament cells }\end{array}$ & $\begin{array}{c}\text { Enhancing of } \\
\text { the proliferation } \\
\text { and osteogenic } \\
\text { differentiation of hPDL } \\
\text { cells }\end{array}$ \\
\hline $\begin{array}{l}\text { Huang et } \\
\text { al. (2013) }\end{array}$ & diode $(670 \mathrm{~nm})$ & $\begin{array}{c}\text { human } \\
\text { periodontal } \\
\text { ligament cells }\end{array}$ & $\begin{array}{l}\text { Positive variation in } \\
\text { irradiated hPDLSCs } \\
\text { compared to non- } \\
\text { irradiated ones. }\end{array}$ \\
\hline $\begin{array}{l}\text { Soares et } \\
\text { al. }(2013)\end{array}$ & $\begin{array}{l}\text { InGaAIP } \\
(660 \mathrm{~nm})\end{array}$ & $\begin{array}{c}\text { human } \\
\text { periodontal } \\
\text { ligament cells }\end{array}$ & $\begin{array}{l}\text { Small changing on the } \\
\text { proliferation rate of } \\
\text { hPDLSC }\end{array}$ \\
\hline
\end{tabular}


The flogosis markers expression like iNOS, COX-2, MMP-3, IL-1 and $\mathrm{OC}$ activity showed a remarkable positive variation in irradiated HPDLSCs at days 1 and 5 in the $-100 \mathrm{kPa}$ incubator compared to non-irradiated ones. LLLT irradiation seems to improve periodontal parameters [84] and HPDLSCs showed good response grown onto 3D scaffold in the osteogenic differentiation [85]. These results suggested that LLLT and HPDLSCs have a role in the maintenance of the alveolar bone [23] and they are helpful in healing inflammation and may, in the future, augment regeneration procedures such as the tooth movement rate even if it is not yet showed definitively by other papers [86-91]. The most relevant papers focusing on LLLT and HPDLSCs are reported in Table 1.

\section{Effects on HDPSCs}

The hDPSCs can be collected from the pulp of all permanent teeth (in particular from third molars) and exfoliated deciduous teeth [92]. They can be detached and augmented showing multipotential plasticity [11,27-30,32-38,93] and immunosuppressive activity, that could be considered an added value during healing, reconstructive and transplantation procedures [31]. In particular, their most feasible and promising application is related to bone regeneration [36]. Ginani [94] founded pulp stem cells from permanent teeth exhibited higher proliferation analyzed at two times $(72 \mathrm{~h}$ and $96 \mathrm{~h}$ after irradiation) when irradiated with wavelength of $660 \mathrm{~nm}$ and the dose of $1.0 \mathrm{~J} / \mathrm{cm}^{2}$ compared to the non-irradiated control group.

Table 2: Main papers of LLLT on HDPSCs.

\begin{tabular}{|c|c|c|c|}
\hline $\begin{array}{c}\text { Authors } \\
\text { (Year) }\end{array}$ & $\begin{array}{c}\text { Laser } \\
\text { Wavelength }\end{array}$ & $\begin{array}{c}\text { Cell/Tissue } \\
\text { Examined }\end{array}$ & Conclusion \\
\hline $\begin{array}{c}\text { Ginami } \\
(2017)\end{array}$ & $\begin{array}{c}\text { InGaAlP } \\
(660 \mathrm{~nm})\end{array}$ & $\begin{array}{c}\text { human } \\
\text { exfoliated } \\
\text { deciduous teeth }\end{array}$ & $\begin{array}{c}\text { LLLT promote the } \\
\text { proliferation of SHEDs } \\
\text { and the maintenance of } \\
\text { cell viability. }\end{array}$ \\
\hline $\begin{array}{c}\text { Arany } \\
(2014)\end{array}$ & $\begin{array}{c}\text { GaAlAs } \\
(810 \mathrm{~nm})\end{array}$ & $\begin{array}{c}\text { human dental } \\
\text { pulp stem cells }\end{array}$ & $\begin{array}{c}\text { LLLT promote the } \\
\text { activity of TGF- } \beta 1 \text { that } \\
\text { differentiates stem cells } \\
\text { promoting dentin. }\end{array}$ \\
\hline $\begin{array}{c}\text { Pinheiro } \\
(2017)\end{array}$ & $\begin{array}{c}\text { InGaAlP } \\
(660 \mathrm{~nm})\end{array}$ & $\begin{array}{c}\text { heciduous pulp } \\
\text { stem cells }\end{array}$ & $\begin{array}{c}\text { LLLT on hDPSCs } \\
\text { enhance regeneration in } \\
\text { bone tissue in cleft and } \\
\text { non-cleft patients }\end{array}$ \\
\hline
\end{tabular}

In a recent investigation Arany [95] demonstrated that lowpower laser irradiation (810-nm GaAlAs diode laser) can be used as a minimally invasive tool promote the activity of an endogenous latent growth factor complex in the dental pulp, transforming growth factor- $\beta 1$ (TGF- $\beta 1$ ), that subsequently differentiate human dental stem cells to promote dentin regeneration. Other authors like Pinheiro [96] who stimulated for three weeks the hDPSCs with a low-power red $660 \mathrm{~nm}$ laser at 5, 10, and $20 \mathrm{~J}$ observed their potential in bone tissue regeneration in cleft and noncleft patients. In particular the best pool of hDPSCs seems to be collected from the exfoliated deciduous teeth as showed by Ginani who irradiated these cells with a $660 \mathrm{~nm}$ laser at $30 \mathrm{~mW}$ with a dose of $1.0 \mathrm{~J} / \mathrm{cm}^{2}$ [97]. Recently Staffoli [98], Ching [99], Morsczeck [100,101], Diomede [92] and Bressel [102] highlighted once again the encouraging data available in literature, which will lead soon to personalized therapies, and regenerative approaches dental stem cells based. The most relevant papers focusing on LLLT and HDPSCs are reported in Table 2 .

\section{Effects on HBMSCs and HADSCs}

Other sources of human mesenchymal stem cells investigated in time for bone regeneration are represented by human bone marrow-derived stem cells (HBMSCs) and adult adipose-derived stem cells (HADSCs) from adults. HBMSCs are easily and safely obtained by means of percutaneous withdrawal from the patient's bone marrow, and due to their multilineage potential, they can be stimulated to generate non-hematopoietic tissue, including bone, cartilage, tendons, and ligaments [26]. Particularly, bone marrowderived MSCs differentiate into the osteogenic lineage, if cultured in presence of dexamethasone, ascorbic acid, and $\alpha$-glycerophosphate (osteogenic medium). Soleimani [15] investigated effects of LLLT on HBMSCs proliferation and differentiation into neuron and osteoblast using different energy densities.

He found that LLLT promoted hBMSCs proliferation significantly at all energy densities except for $6 \mathrm{~J} / \mathrm{cm}^{2}$ in comparison to control groups on the seventh day of differentiation. LLLT at energy densities of 3 and $6 \mathrm{~J} / \mathrm{cm}^{2}$ dramatically facilitated the differentiation of HBMSCs into neurons and also, alkaline phosphatase activity was significantly enhanced in irradiated hBMSCs differentiated to osteoblast on the second, fifth, seventh, and tenth day of differentiation. He concluded that using LLLT at $810 \mathrm{~nm}$ wavelength enhances HBMSCs differentiation into neuron and osteoblast in the range of 2-6 J/ $\mathrm{cm}^{2}$, and at the same time increases BMSCs proliferation (except for $6 \mathrm{~J} / \mathrm{cm}^{2}$ ).

Leonida [26] reported a significantly increased proliferation of HBMSCs seeded on a three dimensional scaffold of collagen compared to control group in the first week of LLLT but no further effects in the second week. There were no differences concerning HBMSCs differentiation toward the osteoblastic lineage in the first week but an exponential increase was observed after 14 days of laser irradiation, with respect to the control group. HADSCs were primarily described in 2001 as a population of cells derived from adipose tissue with the potential of differentiation into a number of mesenchymal cell types, includingosteoblasts, chondrocytesand adipocytes [17]. Mvula [103] reported that LLLT at $5 \mathrm{~J} / \mathrm{cm}^{2}$ using $636 \mathrm{~nm}$ diode laser in combination with EGF increased the viability and proliferation of HADSCs, assessed using adenosine triphosphate (ATP) luminescence and optical density at 0,24 and 48 hours after irradiation. De Villiers [19] investigated effects of LLLT on HADSCs, differentiated into smooth muscle cells using retinoic acid, exposed to a $636 \mathrm{~nm}$ diode laser at a $5 \mathrm{~J} / \mathrm{cm}^{2}$.

He found that, morphologically, HADSCs did not show any differences but there was an increase in viability and proliferation post-irradiation. In another research Mvula [17] investigated the effect of low level laser irradiation on primary cultures of hADSCs using a $635-\mathrm{nm}$ diode laser, at $5 \mathrm{~J} / \mathrm{cm}^{2}$ with a power output of 50.2 $\mathrm{mW}$ and a power density of $5.5 \mathrm{~mW} / \mathrm{cm}^{2}$. He reported that cellular morphology did not appear to change after irradiation, there was an increase of cellular viability, measured by ATP luminescence statistically significant at 48 hours, and of proliferation of irradiated 
cells, measured by optical density, at both time points. He also reported that Western blot analysis and immunocytochemical labeling indicated an increase in the expression of stem cell marker $\beta 1$-integrin after irradiation. The most relevant papers focusing on LLLT and HBMSCs and HADSCs are reported in Table 3.

Table 3: Main papers of LLLT on HBMSCs and HADSCs.

\begin{tabular}{|c|c|c|c|}
\hline $\begin{array}{l}\text { Authors } \\
\text { (Year) }\end{array}$ & $\begin{array}{c}\text { Laser } \\
\text { (Wavelength) }\end{array}$ & $\begin{array}{c}\text { Cell/Tissue } \\
\text { Examined }\end{array}$ & Conclusion \\
\hline $\begin{array}{l}\text { Soleimani et } \\
\text { al. (2010) }\end{array}$ & $\begin{array}{l}\text { GaAlAs } \\
(810 \mathrm{~nm})\end{array}$ & $\begin{array}{l}\text { human bone } \\
\text { marrow stem } \\
\text { cells }\end{array}$ & $\begin{array}{c}\text { Increased } \\
\text { differentiation into } \\
\text { neuron and osteoblast } \\
\text { in the range of } 2-6 \mathrm{~J} / \\
\mathrm{cm}^{2} \text { and proliferation } \\
\text { except for } 6 \mathrm{~J} / \mathrm{cm}^{2}\end{array}$ \\
\hline $\begin{array}{l}\text { Leonida et } \\
\text { al. (2010) }\end{array}$ & $\begin{array}{c}\text { NdYag } \\
(1064 n m)\end{array}$ & $\begin{array}{l}\text { human bone } \\
\text { marrow stem } \\
\text { cells }\end{array}$ & $\begin{array}{l}\text { Significant increase } \\
\text { of proliferation in } \\
\text { the first week and } \\
\text { differentiation during } \\
\text { the second week }\end{array}$ \\
\hline $\begin{array}{l}\text { Mvula et al. } \\
\quad(2008)\end{array}$ & $\begin{array}{c}\text { diode } \\
(635 \mathrm{~nm})\end{array}$ & $\begin{array}{l}\text { human } \\
\text { adipose stem } \\
\text { cells }\end{array}$ & $\begin{array}{c}\text { Increasing cellular } \\
\text { viability, proliferation, } \\
\text { and expression of } \beta 1 \text { - } \\
\text { integrin }\end{array}$ \\
\hline $\begin{array}{l}\text { Mvula et al. } \\
\text { (2010) }\end{array}$ & $\begin{array}{c}\text { diode } \\
(636 \mathrm{~nm})\end{array}$ & $\begin{array}{c}\text { human } \\
\text { adipose stem } \\
\text { cells }\end{array}$ & $\begin{array}{l}\text { Increased cell viability } \\
\text { and proliferation }\end{array}$ \\
\hline $\begin{array}{l}\text { De Villier et } \\
\text { al. (2011) }\end{array}$ & $\begin{array}{c}\text { diode } \\
(636 \mathrm{~nm})\end{array}$ & $\begin{array}{c}\text { human } \\
\text { adipose stem } \\
\text { cells }\end{array}$ & $\begin{array}{l}\text { No differences in } \\
\text { morphology, increased } \\
\text { cell viability and } \\
\text { proliferation }\end{array}$ \\
\hline
\end{tabular}

\section{Discussion}

The biological outcome of laser irradiation is influenced by many variables, like: wavelength, spot diameter, energy and power density, duration and rate of irradiation, medium or plate variables, nutritional conditions and the pools of cell irradiated. All the studies analyzed showed qualitative and quantitative different parameters and for this reason it is very difficult to compare them and to identify a univocal protocol. Nearly all papers showed that LLLT had a positive effect on HPDLSCs, hDPSCs, hBMSCs and hADSCs proliferation with doses used between 0.5 and $10 \mathrm{~J} / \mathrm{cm}^{2}$, while doses higher than $10 \mathrm{~J} / \mathrm{cm}^{2}$ exert or no effects [7] or seems to be antiproliferative [93] and similar outcomes were found for LED [104]. In addition, no study showed deleterious effects of LLLT on these cells [105]. The majority of studies about LLLT focus on hPDLSCs probably due to the major interest in periodontal regeneration and speeding up orthodontic treatments $[14,66,71]$.

At the best of our knowledge there is no studies performed on hPDLSCs and hDPSCs in-vivo and for this reason they cannot always mimic clinical conditions, so the limitations of these in vitro studies should be considered but there are some animal studies highlighting possible indications in the regeneration of smooth, skeletal muscle cells and infarcted myocardium [106-111].

\section{Conclusion}

LLLT seems to be effective in stimulating HPDLSCs, HDPSCs, hBMSCs and HADSCs proliferation but there is no unique protocol due to the very high heterogeneity of studies. The synergy between
LLLT and stem cells can open new possibilities in the tissue regeneration, but until now there are no reliable studies performed in vivo on humans. For this reason further studies, especially in vivo on human stem cells, should be performed to validate this promising therapy and to establish an easy and appropriate standardized protocol to provide the best clinical advantage for the patients.

\section{References}

1. Mester E, Szende B, Gärtner P (1967) Effect of laser on hair growth of mice. Kiserletes Orvostudomany 19: 628-631.

2. Borzabadi-Farahani A (2016) Effect of low-level laser irradiation on proliferation of human dental mesenchymal stem cells; a systemic review. J Photochem Photobiol B 162: 577-582.

3. Habib FA, Gama SK, Ramalho LM (2010) Metrical and histological investigation of the effects of low-level laser therapy on orthodontic tooth movement. Photomed Laser Surg 28: S31-S35.

4. Hakki SS, Bozkurt SB (2010) Effects of different setting of diode laser on the mRNA expression of growth factors and type I collagen of human gingival fibroblasts. Photomed Laser Surg 28: 82.

5. Fujimoto K, Kiyosaki T, Mitsui N, Suzuki N, Shimizu N, et al. (2010) Low-intensity laser irradiation stimulates mineralization via increased BMPs in MC3T3-E1 cells. Photomed Laser Surg 42(6): 519-526.

6. Caccianiga G, Cordasco G, Leonida A, Carinci F, Crestale C, et al. (2012) Periodontal effects with self-ligating appliances and laser biostimulation Dent Res J 9(Suppl 2): S186-S191.

7. Pereira LO, Figueiro Longo JP, Bentes Azevedo R (2012) Laser irradiation did not increase the proliferation or the differentiation of stem cells from normal and inflamed dental pulp. Arch Oral Biol 10791085.

8. Kneebone WJ, Cnc DIH, Fiama D (2006) Practical applications of low level laser therapy. Pract Pain Manage 6(8): 34-40.

9. Pretel H, Oliveira JA, Lizarelli RFZ, Ramalho LTO (2009) Evaluation of dental pulp repair using low level laser therapy (688 $\mathrm{nm}$ and $785 \mathrm{~nm}$ ) morphologic study in capuchin monkeys. Laser Phys Lett 6(2): 149158.

10. Godoy BM, Arana-Chavez VE, Nunez SC, Ribeiro MS (2007) Effects of low-power red laser on dentine-pulp interface after cavity preparation. An ultrastructural study. Arch Oral Biol 52(9): 899-903.

11. Eduardo FP, Bueno DF, Freitas PM, Eduardo Cde P, Zatz M, et al. (2008) Stem cell proliferation under low intensity laser irradiation: a preliminary study. Lasers Surg Med 40: 433-438.

12. Caccianiga G, Crestale C, Cozzani M, Piras A, Mutinelli S, et al. (2016) Low-level laser therapy and invisible removal aligners. J biol regul homeos agents 30(2 Suppl 1): 107-113.

13. Wu Y, Wang J, Gong D, Gu H, Hu S,et al. (2012) Effects of low-level laser irradiation on mesenchymal stem cell proliferation: a microarray analysis. Lasers Med Sci 27(2): 509-519.

14. Caccianiga G, Paiusco A, Perillo L, Nucera R, Pinsino A, et al. (2017) Does low-level laser therapy enhance the efficiency of orthodontic dental alignment? Results from a randomized pilot study. Photomedicine and laser surgery 35(8): 421-426.

15. Soleimani M, Abbasnia E, Fathi M, Sahraei H, Fathi Y, et al. (2012)The effects of low-level laser irradiation on differentiation and proliferation of human bone marrow mesenchymal stem cells into neurons and osteoblasts: an in vitro study. Lasers Med Sci 27(2): 423-430.

16. Caccianiga G, Cordasco G, Leonida A, Zorzella P, Squarzoni N, et al. (2012) Periodontal effects with selfligating appliances and laser biostimulation. Dental research journal 9(Suppl 2): S186.

17. Mvula B, Mathope T, Moore T, Abrahamse H (2008) The effect of lowlevel laser irradiation on adult human adipose-derived stem cells. Lasers Med Sci 23: 277-282. 
18. Caccianiga G, Rey G, Baldoni M,Paiusco A (2016) Clinical, radiographic and microbiological evaluation of high level laser therapy, a new photodynamic therapy protocol, in peri-implantitis treatment; a pilot experience. BioMed research international 2016: 6321906.

19. Grassia V, Gentile E, Di Stasio D, Jamilian A, Matarese G, et al. (2016) In vivo confocal microscopy analysis of enamel defects after orthodontic treatment: A preliminary study. Ultrastruct Pathol 40(6): 317-323.

20. Caccianiga G, Cambini A, Donzelli E, Baldoni M, Rey G, et al. (2016) Effects of laser biostimulation on the epithelial tissue for keratinized layer differentiation: an in vitro study. Journal of biological regulators and homeostatic agents 30(2 Suppl 1): 99-105.

21. Wu JY, Chen CH, Yeh LY, Yeh ML, Ting CC, et al. (2013) Low-power laser irradiation promotes the proliferation and osteogenic differentiation of human periodontal ligament cells via cyclic adenosine monophosphate. Int J Oral Sci 5(2): 85-91.

22. Caccianiga G, Rey G, Paiusco A, Lauritano D, Cura F, et al. (2016) Oxygen high level laser therapy is efficient in treatment of chronic periodontitis: A clinical and microbiological study using PCR analysis. Jbiol regul homeost agents 30(2 Suppl 1): 87-97.

23. Tuby H, Maltz L, Oron U (2007) Low-level laser irradiation (LLLI) promotes proliferation of mesenchymal and cardiac stemcells in culture. Lasers Surg Med 39: 373-378.

24. Caccianiga G, Baldoni M, Ghisalberti C A, Paiusco A (2016)A preliminary in vitro study on the efficacy of high-power photodynamic therapy (HLLT): comparison between pulsed diode lasers and superpulsed diode lasers and impact of hydrogen peroxide with controlled stabilization. BioMed research international 2016: 1386158.

25. Park JC, Lee SM, Kim JC, Yun JH, Cho KS, et al. (2012) Effect of humoral factors from hPDLSCs on the biologic activity of hABCs. Oral Dis 18(6): 537-547.

26. Leonida A, Paiusco A, Rossi G, Carini F, Baldoni M, et al. (2013) Effects of low-level laser irradiation on proliferation and osteoblastic differentiation of human mesenchymal stem cells seeded on a threedimensional biomatrix: in vitro pilot study. Lasers Med Sci 28: 125132.

27. Gronthos S, Mankani M, Brahim J (2000) Postnatal human dental pulp stem cells (DPSCs) in vitro and in vivo. Proceedings of the National Academy of Sciences USA 97: 13625-13630.

28. Shi S, Gronthos S (2003) Perivascular niche of postnatal mesenchymal stem cells in human bone marrow and dental pulp. J Bone Miner Res 18: 696-704.

29. Kerkis I, Kerkis A, Dozortsev D, Stukart-Parsons GC, Gomes Massironi SM, Pereira LV, et al. (2006) Isolation and characterization of a population of immature dental pulp stem cells expressing OCT-4 and other embryonic stem cells markers. Cells Tissues Organs 184(3-4): 105-116.

30. De Mendonc A, Costa AM, Bueno DF, Kerkis I, Kerkis A, et al. (2008) Reconstruction of large cranial defects in non-immunosupressed rats with human stem cells: A preliminary report. J Craniofac Surg 19(1): 204-210.

31. Pierdomenico L, Bonsi L, Calvitti M, Rondelli D, Arpinati M, et al. (2005) Multipotent mesenchymal stem cells with immunosuppressive activity can be easily isolated from dental pulp. Transplantation 80: 836-842.

32. La Noce M, Paino F, Spina A,Naddeo P, Montella R, et al. (2014) Dental pulp stem cells: State of the art and suggestions for a true translation of research into therapy. J Dent 42(7): 761-768.

33. Mitsiadis TA, Feki A, Papaccio G, Catón J (2011) Dental pulp stem cells, niches, and notch signaling in Tooth Injury. Adv Dent Res 23(3): 275279.

34. Tirino V, Paino F, De Rosa A, Papaccio G (2012) Identification, Isolation, Characterization, and Banking of Human Dental Pulp Stem Cells. Methods Mol Biol 879: 443-463.
35. D’aquino R, De Rosa A, Laino G, Caruso F, Guida L, et al. (2009) Human Dental Pulp Stem Cells: From Biology to Clinical Applications. J Exp Zoo Part B: Molecular and Developmental Evolution 312B(5): 408-415.

36. D’aquino R, Papaccio G, Laino G, Graziano A (2008) Dental Pulp Stem Cells: A Promising Tool for Bone Regeneration. Stem Cell Rev 4(1): 2126.

37. Tirino V, Paino F, D’aquino R, Desiderio V, De Rosa A, et al. (2011) Methods For The Identification, Characterization And Banking of Human Dpscs: Current Strategies And Perspectives. Stem Cell Rev 7(3): 608-615.

38. Laino G, Carinci F, Graziano A, D’aquino R, Lanza V, et al. (2006) In vitro Bone Production Using Stem Cells Derived From Human Dental Pulp. J Craniofac Surg 17(3): 511-515.

39. Zuk PA, Zhu M, Ashjian P, Huang JI, Mizuno H, et al. (2002) Human adipose tissue is a source of multipotent stem cells. Molecular Biology of the Cell 13: 4279-4295.

40. Woodruff LD, Bounkeo JM, Brannon WM, Dawes KS, Barham CD, et al. (2004) The efficacy of laser therapy in wound repair: A meta-analysis of the literature. Photomed Laser Surg 22(3): 241-247.

41. Secco M, Zucconi E, Vieira NM, Fogaça LL, Cerqueira A, et al. (2008) Multipotent stem cells from umbilical cord: Cord is richer than blood. Stem Cells 26(1): 146-150.

42. Desiderio V, De Francesco F, Schiraldi C, De Rosa A, La Gatta A, et al. (2013) Human Ng2+ adipose stem cells loaded in vivo on a new crosslinked hyaluronic acid-Lys scaffold fabricate a skeletal muscle tissue. J Cell Physiol 228(8): 1762-1773.

43. De Francesco F, Tirino V, Desiderio V, Ferraro G, D'Andrea F, et al. (2009) Human CD34/CD90 ASCs are capable of growing as sphere clusters, producing high levels of VEGF and forming capillaries. Public Library of Science 4(8): e6537.

44. De Rosa A, De Francesco F, Tirino V, Ferraro GA, Desiderio V, et al. (2009) A new method for cryopreserving adipose-derived stem cells: an attractive and suitable large-scale and long-term cell banking technology. Tissue Eng Part C Methods 15(4): 659-667.

45. D’Andrea F, De Francesco F, Ferraro GA, Desiderio V, Tirino V, et al. (2008) Large-scale production of human adipose tissue from stem cells: a new tool for regenerative medicine and tissue banking. Tissue Eng Part C Methods 14(3): 233-242.

46. Caplan AI (1991) Mesenchymal stem cells. J Orthop Res 9: 641-650.

47. Kuznetsov SA, Krebsbach PH, Satomura K, Kerr J, Riminucci M, et al. (1997)Single-colony derived strains of human marrow stromal fibroblasts form bone after transplantation in vivo. J Bone Miner Res 12: $1335-1347$.

48. Henze K, Martin W (2003) Evolutionary biology: essence of mitochondria. Nature. 426 (6963): 127-128.

49. Connelly NG, Geiger WE (1996) Chemical Redox Agents for Organometallic Chemistry. Chem Rev 96 (2): 877-910.

50. Jonckheere AI, Smeitink JAM, Rodenburg RJT (2017) Mitochondrial ATP synthase: architecture, function and pathology. J Inherit Metab Dis 35(2): 211-225.

51. Berg JM, Tymoczko JL, Stryer L (2002) A Proton Gradient Powers the Synthesis of ATP. Bio chemistry 5thedition.

52. Kim HS, Pat el K, Muldoon-Jacobs K, Bisht KS, Aykin-Burns N, et al. (2010) SIRT3 is a mitochondria-localized tumor suppressor required for maintenance of mitochondrial integrity and metabolism during stress. Cancer Cell 17 (1): 41-52.

53. Stein A, Benayahu D, Maltz L, Oron U (2005) Low-level laser irradiation promotes proliferation and differentiation of human osteoblasts in vitro. Photomed Laser Surg 23: 161-166.

54. Karu T (1989) Laser biostimulation: A photobiological phenomenon. J Photochem Photobiol B 3: 638-640. 
55. Karu T (1989) Photobiology of low-power laser effects. Health Physics 56: 691-704.

56. Friedmann H, Lubart R, Laulicht I, Rochkind S (1991) A possible explanation of laser-induced stimulation and damage of cell cultures. J Photochem Photobiol B 11: 87-91.

57. McBride HM, Neuspiel M, Wasiak S (2006) Mitochondria: more than just a powerhouse. Curr Biol 16(14): R55160.

58. Ferraresi C, Kaippert B, Avci P, Huang YY, Pires de Sousa MV, et al. (2015) Low-level laser (light) therapy increases mitochondrial membrane potential and ATP synthesis in C2C12 myotubes with a peak response at 3-6 hours. Photochem Photobiol 91(2): 411-416.

59. Houreld NN, Masha RT, Abrahamse H (2012) Low-intensity laser irradiation at $660 \mathrm{~nm}$ stimulates cytochrome c oxidase in stressed fibroblast cells. Lasers Surg Med 44(5): 429-434.

60. Freitas P, Novaretti CP, Rodini CO, Batista AC, Lara VS (2007) Mast cells and lymphocyte subsets in pulps from healthy and carious human teeth. Oral Surg Oral Med Oral Pathol Oral Radiol Endod 103(5): e95-e102.

61. Miller GS, Sternberg RN, Piliero SJ, Rosenberg PA (1978) Histologic identification of mast cells in human dental pulp. Oral Surg Oral Med Oral Pathol 46(4): 559-566.

62. Bayat M, Vasheghani MM, Razavie N, Jalili MRJ (2008) Effects of lowlevel laser therapy on mast cell number and degranulation in thirddegree burns of rats. Rehabil Res Dev 45(6): 931-938.

63. Matarese G, Isola G, Pio Anastasi G, Favaloro A, Milardi D, et al.(2013) Trasforming growth factor Beta1 and vascular epithelial growth factor in the pathogenesis of periodontal desease. European Journal of Inflammation 11(2): 479-488.

64. Wang L, Zhang D, Schwarz W (2014) TRPV Channels in Mast Cells as a Target for Low-Level-Laser Therapy. Cells 3(3): 662-673.

65. Kumar GS (2011) Orban's Oral Histology and Embryology $\left(13^{\text {th }}\right.$ Edition). Elsevier pp: 172.

66. Camerlingo C, d'Apuzzzo F, Grassia V, Perillo L, Lepore M (2014) MicroRaman spectroscopy for monitoring changes in periodontal ligament and gingival crevicular fluid. Sensors 14: 22552-22563.

67. Di Domenico M, d'Apuzzo F, Feola A, Monsurrò A, Pierantoni GM, et al. (2012) Cytokines and VEGF Induction in Orthodontic Movement in Animal Models. J Biomed Biotechnol 201689.

68. Hou JF, Zhang H, Yuan H, Li J, Wei YJ, et al. (2008) In vitro effects of low-level laser irradiation for bone marrow mesenchymal stem cells: proliferation, growth factors secretion and myogenic differentiation. Lasers Surg Med 40(10): 726-733.

69. Soleimani M, Abbasnia E, Fathi M, Sahraei H, Fathi Y, et al. (2012) The effects of low-level laser irradiation on differentiation and proliferation of human bone marrow mesenchymal stem cells into neurons and osteoblasts - an in vitro study. Lasers Med Sci 27(2): 423-430.

70. Silva AP, Petri AD, Crippa GE, Stuani AS, Rosa AL, et al. (2012) Effect of low-level laser therapy after rapid maxillary expansion on proliferation and differentiation of osteoblastic cells. Lasers Med Sci 27(4): 777-783.

71. Perinetti G, D’Apuzzo F, Contardo L, Primozic J, Rupel K, Perillo L (2015) Gingival crevicular fluid alkaline phosphate activity during the retention phase of maxillary expansion in prepubertal subjects: a splitmouth longitudinal study. Am J Orthod Dentofacial Orthop 148: 90-96.

72. Kim JH, Ko SY, Lee JH, Kim DH, Yun JH (2017) Evaluation of the periodontal regenerative properties of patterned human periodontal ligament stem cell sheets. J Periodontal Implant Sci 47(6): 402-415.

73. Huang TH, Liu SL, Chen CL, Shie MY, Kao CT (2013) Low-level laser effects on simulated orthodontic tension side periodontal ligament cells. Photomed Laser Surg 31(2): 72-77.
74. de Oliveira GJPL, Aroni MAT, Medeiros MC, Marcantonio EJr, Marcantonio RAC (2018) Effect of low-level laser therapy on the healing of sites grafted with coagulum, deproteinized bovine bone, and biphasic ceramic made of hydroxyapatite and $\beta$-tricalcium phosphate. In vivo study in rats. Lasers Surg Med 13.

75. Shimizu N, Yamaguchi M, Goseki T, Shibata Y, Takiguchi H, et al. (1995) Inhibition of prostaglandin E2 and interleukin 1-beta production by low-power laser irradiation in stretched human periodontal ligament cells. J Dent Res 74(7): 1382-1388.

76. Ozawa Y, Shimizu N, Abiko Y (1997) Low-energy diode laser irradiation reduced plasminogen activator activity in human periodontal ligament cells. Lasers Surg Med 21(5): 456-463.

77. Lee JH, Um S, Jang JH, Seo BM (2012) Effects of VEGF and FGF-2 on proliferation and differentiation of human periodontal ligament stem cells. Cell Tissue Res 348(3): 475-484.

78. Yu Y, Mu J, Fan Z, Yan M, Wang S, et al. (2012) Insulin-like growth factor 1 enhances the proliferation and osteogenic differentiation of human periodontal ligament stem cells via ERK and JNK MAPK pathways. Histochem Cell Biol 137(4): 513-525.

79. Zhou Y, Wu C, Xiao Y (2012) The stimulation of proliferation and differentiation of periodontal ligament cells by the ionic products from Ca7Si2P2016 bioceramics. Acta Biomater 8(6): 2307-2316.

80. Xia L, Zhang Z, Chen L, Zhang W, Zeng D, et al. (2011) Proliferation and osteogenic differentiation of human periodontal ligament cells on akermanite and beta-TCP bioceramics. Eur Cell Mater 22: 68-83.

81. Kreisle M, Christoffers AB, Al-Haj H, Willershausen B, d'Hoedt B (2002) Low level 809-nm diode laser-induced in vitro stimulation of the proliferation of human gingival fibroblasts. Lasers Surg Med 30: 365-336.

82. Kreisle M, Christoffers AB, Willershausen B, d'Hoedt B (2003) Effect of low-level GaAlAs laser irradiation on the proliferation rate of human periodontal ligament fibroblasts: an in vitro study. J Clin Periodontol 30(4): 353-358.

83. Soares DM, Ginani F, Henriques AG, Barboza CA (2015) Effects of laser therapy on the proliferation of human periodontal ligament stem cells. Lasers Med Sci 30: 1171-1174.

84. Gündoğar H, Şenyurt SZ, Erciyas K, Yalım M, Üstün K (2016) The effect of low-level laser therapy on non-surgical periodontal treatment: a randomized controlled, single-blind, split-mouth clinical trial. Lasers Med Sci 31: 1767-1773.

85. Diomede F, Merceron I, Martinotti S, Cavalcanti MF, Caputi S, et al. (2016) miR-2861 is involved in osteogenic commitment of human periodontal ligament stem cells grown onto 3D scaffold. J Biol Regul Homeost 30(4): 1009-1018.

86. Fekrazad R, Asefi S, Allahdadi M, Kalhori KA (2016) Effect of Photobiomodulation on Mesenchymal Stem Cells. Photomed Laser Surg 34(11): 533-542.

87. Gunji H, Kunimatsu R, Tsuka Y, Yoshimi Y, Sumi K, et al. (2018) Effect of high-frequency near-infrared diode laser irradiation on periodontal tissues during experimental tooth movement in rats. Lasers Surg Med.

88. Suzuki SS, Garcez AS, Reese PO, Suzuki H, Ribeiro MS, et al. (2017) Effects of corticopuncture (CP) and low-level laser therapy (LLLT) on the rate of tooth movementand root resorption in rats using micro-CT evaluation. Lasers Med Sci 33: 81-821.

89. Qamruddin I, Alam MK, Mahroof V, Fida M, Khamis MF, et al. (2017) Effects of low-level laser irradiation on the rate of orthodontic tooth movement and associated pain with self-ligating brackets. Am J Orthod Dentofacial Orthop 152(5): 622-630.

90. Mancini GE, Carinci F, Zollino I, Avantaggiato A, Puglisi P, et al. (2011) Effectiveness of self-ligating orthodontic treatment. Eur J Inflamm 9: 53-58. 
91. Martignago, Cintia , F Oliveira, RPires Oliveira, DeiseOliveira, PriscilaPacheco Soares, et al.(2014) Effect of low-level laser therapy on the gene expression of collagen and vascular endothelial growth factor in a culture of fibroblast cells in mice. Lasers Med Sci 30: 203-208.

92. Diomede F, Gugliandolo A, Scionti D, Merciaro I, Cavalcanti MF, et al. (2018) Biotherapeutic Effect of Gingival Stem Cells Conditioned Medium in Bone Tissue Restoration. Int J Mol Sci 19(2).

93. Tirino V, Papaccio G (2012) A new, most likely unusual approach is crucial and upcoming for the use of stem cells in regenerative medicine. Front Physiol 2: 119.

94. Ginani F, Soares DM, Rocha ODR,De Souza LB, Galvão Barboza CA (2017) Low-level laser irradiation induces in vitro proliferation of stem cells from human exfoliated deciduous teeth. Lasers Med Sci 10: 211-218.

95. Arany PR, Cho A, Hunt TD, Shin K4, Hahm E, et al. (2014) Photoactivation of endogenous latent transforming growth factor- $\beta 1$ directs dental stem cell differentiation for regeneration. Sci Transl Med 6 (238): 69.

96. Pinheiro CCG, de Pinho MC, Aranha AC, Fregnani E, Bueno DF (2018) Low Power Laser Therapy: A Strategy to Promote the Osteogenic Differentiation of Deciduous Dental Pulp Stem Cells from Cleft Lip and Palate Patients. Tissue Eng Part A 24: 569-575.

97. Ginani F, Soares DM, de Oliveira Rocha HA, de Souza LB, Barboza CAG (2018) Low-level laser irradiation induces in vitro proliferation of stem cells from human exfoliated deciduous teeth. Lasers Med Sci 33(1): 95-102.

98. Staffoli S, Romeo U, Amorim RNS, Migliau G, Palaia G, et al. (2017) The effects of low level laser irradiation on proliferation of human dental pulp: a narrative review. Clin Ter 168(5): e320-e326.

99. Ching HS, Luddin N, Rahman IA, Ponnuraj KT (2017) Expression of Odontogenic and Osteogenic Markers in DPSCs and SHED: A Review. Curr Stem Cell Res Ther 12(1): 71-79.

100. Morsczeck C, Reichert TE (2018) Dental stem cells in tooth regeneration and repair in the future. Expert Opin Biol Ther 18(2):187-196.

101. Morsczeck C, Hullmann M, Reck A, Reichert TE (2018) The cell cycle regulator protein P16 and the cellular senescence of dental follicle cells. Mol Cell Biochem 439(1-2): 45-52.

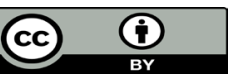

This work is licensed under Creative Commons Attribution 4.0 License

Submission Link: https://biomedres.us/submit-manuscript.php
102. Bressel TAB, de Queiroz JDF, Gomes Moreira SM, da Fonseca JT, Filho EA, et al. (2017) Laser-modified titanium surfaces enhance the osteogenic differentiation of human mesenchymal stem cells. Stem Cell Res Ther 8(1): 269.

103. Mvula B, Moore TJ, Abrahamse H (2010) Effect of low-level laser irradiation and epidermal growth factor on adult human adiposederived stem cells. Lasers in Medical Science 25(1): 33.

104. Vale KLD, Maria DA, Deana AM, Mascaro MB, Ferrari RAM, et al. (2017) The effects of photobiomodulation delivered by light-emitting diode on stem cells from human exfoliated decidous teeth: a study on the relevance topluripotent stem cell viability and ploriferation. Photomed Laser Surg 9: 128-131.

105. Marques MM, Diniz IMA, De Cara SPHM, Pedroni ACF, Tedesco T, et al. (2016) Photobiomodulation of dental derived mesenchymal stem cells: a systematic review. Photomed Laser Surg 11: 500-508.

106. Khalid AlGhamdi M, Kumar A, Noura A, Moussa (2012) Low-laser therapy: a useful technique for enhancing the proliferation of various cultured cells. Lasers Med Sci 27: 237-249.

107. Ballini A, Scattarella A, Crincoli V, Carlaio RG, Papa F, et al. (2010) Surgical treatment of gingival overgrowth with 10 years of follow up. Head Face Med 12: 6-19.

108. Liu J, Yu F, Sun Y, Jiang B, Zhang W, et al. (2015) Concise reviews: characteristics and potential applications of human dental tissuederived mesenchymal stem cells. Stem Cells 627-638.

109. Ballini A, Tetè S, Scattarella A, Cantore S, Mastrangelo F, et al. (2010) The role of anti-cyclic citrullinated peptide antibody in periodontal disease. Int J Immunopathol Pharmacol 23(2): 677-681.

110. Ong SG, Lee WH, Zhou Y, Wu JC (2018) Mining Exosomal MicroRNAs from Human-Induced Pluripotent Stem Cells-Derived Cardiomyocytes for Cardiac Regeneration. Methods Mol Biol 1733: 127-136.

111. Ovchinnikova E, Hoes M, Ustyantsev K Bomer N de Jong TV ,et al. (2018) Modeling Human Cardiac Hypertrophy in Stem Cell-Derived Cardiomyocytes. Stem Cell Reports 10(3): 794-807.

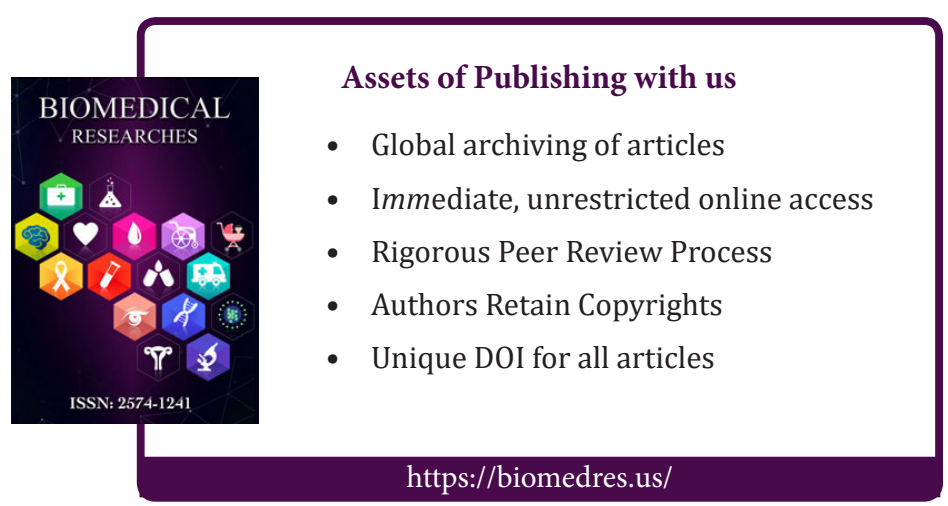

